\title{
Pemanfaatan Daun Kelor (Moringa oleifera) dalam Fortifikasi Pembuatan Nugget
}

\author{
Utilization of Moronga oleifera leaves in Nugget Fortification
}

\author{
Z. Suhaemi ${ }^{*}$, Husmaini ${ }^{2}$, E. Yerizal ${ }^{3}$, \& N. Yessirita ${ }^{4}$ \\ ${ }^{1}$ Fakultas Pertanian, Universitas Tamansiswa, Padang, Sumatera Barat \\ ${ }^{2}$ Fakultas Peternakan, Universitas Andalas, Padang, Sumatera Barat \\ ${ }^{3}$ Fakultas Kedokteran, Universitas Andalas, Padang, Sumatera Barat \\ ${ }^{4}$ Fakultas Pertanian, Universitas Ekasakti, Padang, Sumatera Barat \\ *Corresponding author: emizasmeli@gmail.com \\ (Received 27-12-2020; Revised 20-01-2021; Accepted 29-01-2021)
}

\begin{abstract}
The aimed of this study was to determine the effect of Moringa Leaf Flour (MLF) on chicken and duck meat processed quality formed nugget as fortification. Duck meat has advantages with mineral content, especially iron, about $50 \%$ of the daily needs for adult's body compared to chicken meat which is only 9\%. Duck meat also contains high levels of vitamins B, C and antioxidants, but chicken meat neither. This study was conducted in two stages, the first was nugget experiment with chicken meat, and the second stages with duck meat. The meat used were ground with flour and seasoning. The variables measured were the nutritional content which includes crude protein and fat, also cholesterol total, the other variables were sensory evaluation which include scale of taste, texture and color. This study used completely randomized design with 4 treatments addition of MLF $(0.0 \% ; 0.5 \% ; 1.0 \%$ and $1.5 \%)$, each treatments replicated 5 times. The result show that the more addition of MLF will increased Crude Protein and highly significant decreased crude fat and cholesterol total. In the other hand, addition of MLF was highly significant lowering the taste, texture and color of nugget, but still in acceptable range.
\end{abstract}

Keywords: chicken, duck, fortification, meat, nugget

\begin{abstract}
ABSTRAK
Tujuan dari penelitian ini adalah untuk mengetahui manfaat Tepung Daun Kelor (TDK) dalam fortifikasi pembuatan nugget ayam dan itik. Pembuatan nugget umumnya menggunakan daging ayam, padahal daging itik memiliki banyak keunggulan dibanding daging ayam, karena memiliki kandungan mineral yang tinggi khususnya zat besi yang dapat mencukupi $50 \%$ kebutuhan orang dewasa. Daging itik juga kaya akan kandungan vitamin B, C dan antioksidan yang tidak dimiliki daging ayam. Penelitian ini dilakukan dua percobaan, pertama percobaan nugget dengan daging ayam, dan kedua percobaan dengan daging itik. Daging yang digunakan digiling dan ditambahkan tapung serta bumbu. Peubah yang diukur terdiri dari dua bagian, yaitu kandungan nutrisi nugget serta nilai organoleptik. Penelitian dianalisis menggunakan ANOVA yaitu Rancangan Acak Lengkap dengan 4 perlakuan persentase penambahan TDK $(0.0 \% ; 0.5 \% ; 1.0 \%$ dan $1.5 \%)$, serta 5 kali ulangan. Hasil penelitian menunjukkan bahwa semakin tinggi persentase penambahan TDK akan meningkatkan kandungan protein kasar, serta sangat nyata menurunkan lemak kasar dan total kolesterol. Fortifikasi TDK dalam pembuatan nugget, secara umum menurunkan nilai rasa, tekstur dan warna nugget, namun masih dalam batas bisa diterima oleh panelis, dengan penilaian umumnya lebih dari skala 3 .
\end{abstract}

Kata kunci: ayam, itik, nugget, fortifikasi, kelor 


\section{PENDAHULUAN}

Nugget adalah jenis olahan daging restrukturisasi yaitu daging yang digiling dan di bumbui, kemudian diselimuti oleh perekat tepung, pelumuran tepung roti (breading), dan di goreng setengah matang lalu dibekukan untuk mempertahankan mutunya selama penyimpanan. Nugget biasa dibuat dari daging ayam, namun salah satu daging yang juga biasa dikonsumsi manusia dan berpotensi sebagai bahan pembuat nugget adalah daging itik. Penggunaan daging itik sebagai bahan dasar pembuatan nugget sebelumnya telah diteliti (Putri et al. 2019). Dilaporkan bahwa nugget itik dapat diterima oleh masyarakat akan tetapi belum sepenuhnya mampu mensubtitusi daging ayam, karena nugget itik rasanya sudah mencapai tingkat disukai oleh panelis, namun dari segi warna baru sampai pada kriteria agak disukai karena masih kurang menarik dibandingkan dengan warna nugget ayam. Tingkat kesukaan masyarakat terhadap daging itik umumnya lebih rendah jika dibandingkan daging ayam. Aroma amis (off-odor) daging itik lebih menyengat dibanding daging ayam (Lestari et al. 2015). Warna daging yang gelap jika dimasak, aroma yang khas, dan tekstur daging alot menjadi kendala dalam pengolah daging itik (Dinasih et al. 2017).

Komposisi gizi dari daging ini nyaris sebanding dengan daging ayam (Adzitey et al. 2012), kandungan protein daging itik adalah $21.73 \%$, sedangkan ayam $21.28 \%$. Hasil penelitian menunjukkan daging itik mengandung mineral tinggi terutama zat besi, selenium dan niasin, dengan kandungan kalori yang rendah dan protein yang lebih tinggi dibanding daging ayam (El-moursi et al. 2012; Lestari et al. 2020). Seperti halnya daging ayam, daging itik juga dapat digunakan untuk membuat beberapa produk berbasis daging seperti halnya bakso dan sosis (Huda et al. 2010; Huda et al. 2011). Daging itik juga memiliki kelebihan kandungan mineral terutama zat besi yang mampu memenuhi sekitar $50 \%$ kebutuhan harian tubuh orang dewasa dibanding daging ayam yang hanya $9 \%$. Selain itu juga mengandung vitamin $\mathrm{B}, \mathrm{C}$ dan antioksidan yang tinggi, sedangkan daging ayam tidak ada sama sekali. Perkembangan pemahaman mengenai senyawa fungsional dalam pangan menggerakkan kesadaran konsumen tentang kesehatan. Perkembangan pemahaman ini juga berperan membentuk tren modifikasi pangan dengan atribut tambahan berupa fungsi kesehatan (Olmedilla-Alonso 2013). Pendekatan dengan fortifikasi (penambahan zat gizi pada bahan makanan) merupakan salah satu cara yang dapat dilakukan (Adawiyah et al. 2019), salah satunya adalah dengan penambahan daun kelor.

Daun Kelor (Moringa oleifera), kaya akan mineral, vitamin dan kandungan fitokimia. Ekstrak daun kelor banyak digunakan dalam percobaan di bidang malnutrisi, seperti halnya memperlancar ASI juga berpotensi sebagai antioksidan, anti kanker, anti inflammatory, anti diabet dan anti mikroba (Gopalakrishnan et al. 2016). Berdasarkan uji fitokimia daun kelor positif mengandung flavonoid (Immy et al. 2015). Setiap bagian tanaman kelor memiliki kandungan kimia yag bervariasi, daun dan biji serta bunga tanaman ini banyak digunakan sebagan bahan untuk fortifikasi pangan fungsional (food fortificant), seperti pembuatan roti, biskuit, yoghurt, keju atau sup (Oyeyinka dan Oyeyinka 2016). Peneliti sebelumnya melaporkan bahwa dari bagian-bagian tanaman kelor, kandungan nutrisi dan fitokimia terbaik adalah pada daun Kelor (Gopalakrishnan et al. 2016; El-moursi et al. 2012). Daun kelor juga sangat tinggi akan vitamin $\mathrm{C}$ dan $\mathrm{E}$, serta mineral kalsium dan magnesium (Aslam et al. 2005). Analisis laboratrium dari daun kelor menunjukkan kandungan protein $33.89 \%$ dalam bahan kering dengan antoksidan $239.42 \mathrm{ppm}$. Pangan yang mengandung antioksidan sangat dianjurkan untuk mempertahankan fungsi kekebalan dan mengurangi resiko penyakit kardiovaskular (Thomas et al. 2010).

Tepung daun kelor (Moringa oleifera) yang mengandung zat aktif antioksidan dan antibakteri, dianggap mampumeningkatkan kinerja dan mencegah kerusakan organ dalam sehingga berpengaruh baik terhadap peningkatan metabolisme dan penyerapan nutrisi dalam tubuh yang dapat memicu pertumbuhan. Daun Kelor sebagai fortikan pada pangan juga sudah dilakukan sebelumnya. Fitri et al. (2016) melaporkan penambahan tepung daun kelor dalam pembuatan Cokis yang bahan dasarnya tepung terigu. Sedangkan penggunaan daun Kelor dalam pembuatan Mie basah juga sudah dilakukan (Zakaria et al. 2016), namun pemanfaatannya dalam nugget belum ada dilakukan. Inovasi pembuatan nugget itik dengan penambahan daun kelor diprediksi dapat mendongrak kualitas daging ayam dan itik yang kaya akan manfaat sebagai pangan fungsional seperti balita stunting, yang juga akan lebih meningkatkan nilai ekonomis ternak itik.

\section{MATERI DAN METODE}

Penelitian ini terdiri dari dua percobaan nugget, yaitu pertama pembuatan nugget dengan bahan utama daging ayam dan kedua pembuatan nugget dengan bahan utama daging itik. Sebagai gambaran perbedaan antara nugget yang dihasilkan dari daging ayam dan itik. Daging yang digunakan dihaluskan dan dilayukan dengan daun pepaya selama 30 menit, masing-masing 500 gram. Setiap jenis daging ditambahkan 60 gram maizena, 60 gram tepung terigu cakra, 2 butir telur, 3 siung bawang putih, 5 gram gula, garam dan minyak sayur. Seluruh bahan dicampur rata dan dibagi menjadi empat bagian, satu bagian tanpa penambahan tepung daun kelor, satu bagian ditambahkan $0.5 \%$ tepung daun kelor, satu bagian ditambahkan 1.0\% tepung daun kelor dan satu bagian lagi ditambahkan 1.5\% tepung daun kelor.

Bahan yang telah dicampur secara homogen, kemudian dicetak setebal $1 \mathrm{~cm}$, dan dikukus dengan api kecil selama 15 menit. Setelah matang, didinginkan dan dipotong persegi panjang ukuran $1 \times 3 \mathrm{~cm}$. Sebagian bahan yang telah dikukus tersebut, diambil untuk sampel analisis kandungan nutrisi, sebagian lainnya dilampisi lagi dengan putih telur, dan tepung roti. Kemudian digoreng dengan api kecil hingga matang untuk dilakukan uji organoleptik.

Penelitian ini menggunakan analisis of varian (ANOVA) yang disusun dalam Rancangan Acak Lengkap (RAL) dengan perlakuan persentase penambahan tepung daun kelor (TDK) yang terdiri dari 4 perlakuan yaitu: 
$0.0 \% ; 0.5 \% ; 1.0 \%$; dan $1.5 \%$. Hasil analisis yang berbeda nyata akan dilanjutkan dengan uji jarak berganda dunkan (Suhaemi 2011).

Peubah yang diukur dalam penelitian ini terdiri dari dua bagian, yaitu kandungan nutrisi nugget (protein kasar, lemak kasar dan kolesterol total) serta skala nilai organoleptik nugget (rasa, tekstur, dan warna). Rataan skala penilaian organoleptik nugget ditranformasikan dengan $\sqrt{Y}+0.5$ sebelum diuji dengan ANOVA. Penilaian uji organoleptik (rasa, tekstur dan warna) dijelaskan pada Tabel 1. Metode analisis kandungan protein dan lemak mengacu pada metode AOAC (2005), sedangkan analisis kandungan kolesterol total menggunakan ekstrak etanol yang diuji dengan spektrophotometer Microlab 300.

Tabel 1. Skala penilaian uji organoleptik

\begin{tabular}{clcc}
\hline Skala & \multicolumn{1}{c}{ Warna } & Rasa & Tekstur \\
\hline 5 & Kuning nugget & Sangat suka & Sangat suka \\
4 & Kuning kecoklatan & Suka & Suka \\
3 & Coklat & Kurang suka & Kurang suka \\
2 & Coklat agak gelap & Tidak suka & Tidak suka \\
1 & Coklat gelap & Sangat tidak & Sangat tidak \\
& & suka & suka \\
\hline
\end{tabular}

\section{HASIL DAN PEMBAHASAN}

\section{Percobaan Nugget Daging Ayam}

\section{Kandungan nutrisi nugget ayam}

Kandungan nutrisi terhadap nugget daging ayam yang difortifikasi dengan tepung daun kelor (TDK) dapat dilihat pada Tabel 2. Berdasarkan Tabel 2, tergambar bahwa kandungan lemak kasar dan kolesterol nugget semakin menurun, seiring meningkatnya persentase penambahan TDK. Hasil ANOVA menunjukkan bahwa dosis penggunaan TDK menghasilkan perbedaan pengaruh yang sangat nyata terhadap kandungan lemak kasar dan kolesterol nugget ayam $(\mathrm{P}<0.01)$. Berdasarkan uji berjarak berganda dunkan juga didapatkan perbedaan yang sangat nyata $(\mathrm{P}<0.01)$ terhadap kandungan lemak kasar dan kolesterol nugget setiap penambahan dosis TDK dari $0.0 \%$ sampai $1.5 \%$. Hal ini menunjukkan bahwa penambahan TDK dapat meningkatkan nilai nutrisi nugget karena masyarakat yang mengkonsumsi tidak perlu khawatir terhadap kandungan

Tabel 2. Kandungan nutrisi nugget ayam dengan penambahan tepung daun kelor (TDK)

\begin{tabular}{cccc}
\hline TDK (\%) & $\begin{array}{c}\text { Lemak Kasar } \\
(\%)\end{array}$ & $\begin{array}{c}\text { Kolesterol } \\
(\mathrm{mg} / 100 \mathrm{~g})\end{array}$ & $\begin{array}{c}\text { Protein Kasar } \\
(\%)\end{array}$ \\
\hline 0 & $4.08 \pm 0.94 \mathrm{a}$ & $55.3 \pm 3.76 \mathrm{a}$ & $13.42 \pm 1.88$ \\
0.5 & $3.73 \pm 0.72 \mathrm{~b}$ & $52.5 \pm 2.89 \mathrm{~b}$ & $13.57 \pm 1.45$ \\
1 & $2.96 \pm 0.51 \mathrm{c}$ & $45.4 \pm 2.05 \mathrm{c}$ & $13.63 \pm 1.03$ \\
1.5 & $2.06 \pm 0.45 \mathrm{~d}$ & $34.0 \pm 1.82 \mathrm{~d}$ & $13.87 \pm 0.91$ \\
\hline
\end{tabular}

Rataan pada kolom yang sama dengan superscript yang berbeda menunjukkan berbeda nyata $(\mathrm{P}<0.05)$ lemak dan kolesterol nugget. Kandungan lemak yang tinggi akan berakibat terhadap berbagai penyakit yang berhubungan dengan resiko penyakit kardiovaskular (Thomas et al. 2010).

Hasil penelitian sebelumnya dilaporkan bahwa daun Moringa oleifera mengandung zat bioaktif yang tinggi termasuk di dalamnya saponin, yang dapat menurunkan kandungan kolesterol total produk pangan (VázquezLeón et al. 2017). Hal ini juga dilaporkan oleh peneliti lainnya, bahwa hasil analisis fitokimia daun Moringa oleifera mengandung zat saponin yang mempunyai efek hipolipidemia (efek menurunkan lemak darah) bermanfaat untuk menurunkan aktifitas kolesterol (Saini et al. 2016). Kolesterol dalam darah diangkut oleh low density lipoprotein (LDL) untuk didaur ulang dihati kemudian disimpan ke dalam kantung empedu sebagai asam empedu. Semakin banyak kecernaan lemak, maka semakin banyak garam empedu yang dibutuhkan dan akibatnya akan menurunkan kadar kolesterol (Citrawidi et al. 2012).

Kandungan protein kasar nugget ayam, memperlihatkan kenaikan sejalan dengan penambahan tepung daun kelor (Tabel 2). Semakin tinggi persentase penambahan TDK semakin meningkat juga kandungan Protein Kasar nugget, meskipun tidak berbeda nyata. Hal ini disebabkan daun Moringa oleifera telah dilaporkan banyak penelitian, mengandung protein dan asam amino yang tinggi hingga 30.3\% dengan 19 kandungan asam-asam amino (Moyo et al. 2011).

\section{Nilai organoleptik nugget ayam}

Selain kandungan nutrisi, sebagai pertimbangan masyarakat dalam mengkonsumsi makanan, tidak kalah penting yang menjadi pertimbangan adalah tingkat kesukaan terhadap suatu pangan. Hasil uji organoleptik yang meliputi rasa, tekstur dan warna dari nugget, dengan persentase penambahan TDK yang berbeda dapat dilihat pada Tabel 3. Rataan skala penilaian terhadap rasa berada pada skala $4.20-4.82$, cenderung mendekati skala penilaian yang tertinggi. Skala uji terhadap tekstur yang terendah 3.64 dan tertinggi 4.62, sedangkan warna nugget berada antara skala 3.96 dan 4.91 .

Tabel 3. Skala uji organoleptik nugget ayam dengan penambahan tepung daun kelor (TDK)

\begin{tabular}{cccc}
\hline TDK $(\%)$ & \multicolumn{3}{c}{ Uji organoleptik } \\
\cline { 2 - 4 } & Rasa & Tekstur & Warna \\
\hline 0 & $4.82 \pm 0.39 \mathrm{a}$ & $4.62 \pm 0.49 \mathrm{a}$ & $4.91 \pm 0.27 \mathrm{a}$ \\
0.5 & $4.82 \pm 0.39 \mathrm{a}$ & $4.31 \pm 0.65 \mathrm{~b}$ & $4.68 \pm 0.47 \mathrm{~b}$ \\
1 & $4.70 \pm 0.45 \mathrm{~b}$ & $3.97 \pm 0.62 \mathrm{c}$ & $4.12 \pm 0.59 \mathrm{c}$ \\
1.5 & $4.20 \pm 0.40 \mathrm{c}$ & $3.64 \pm 0.48 \mathrm{~d}$ & $3.96 \pm 0.35 \mathrm{~d}$ \\
\hline
\end{tabular}

Rataan pada kolom yang sama dengan superscript yang berbeda menunjukkan berbeda nyata $(\mathrm{P}<0.05)$

Hasil tersebut menggambarkan bahwa nilai rasa, tekstur dan warna nugget ayam cenderung makin menurun, terutama untuk nilai warna, namun nilai rasa tidak memberikan penurunan yang besar meskipun hasil ANOVA dan uji lanjut semuanya menunjukkan hasil yang 
berbeda sangat nyata $(\mathrm{P}<0.01)$. Semakin tinggi prosentase penambahan TDK, mengakibatkan menurunnya nilai skala rasa nugget. Hal ini sejalan dengan penelitian lain pada pembuatan permen jeli yang menggunakan TDK, peningkatan penggunaan TDK mengakibatkan menurunnya tingkat kesukaan panelis (Rahmawati dan Adi 2017).

Pengaruh penambahan TDK dalam olahan nugget, sangat mempengaruhi warna yang dihasilkan seperti terlihat pada Gambar 1. Hal ini mengakibatkan semakin rendahnya skala nilai warna yang diberikan panelis pada uji organoleptik. Meskipun demikian, rataan skala yang diberikan panelis masih berada di atas 3 (skala tengah) atau masih dapat diterima oleh masyarakat dibandingkan dengan nugget yang biasa beredar dipasaran.

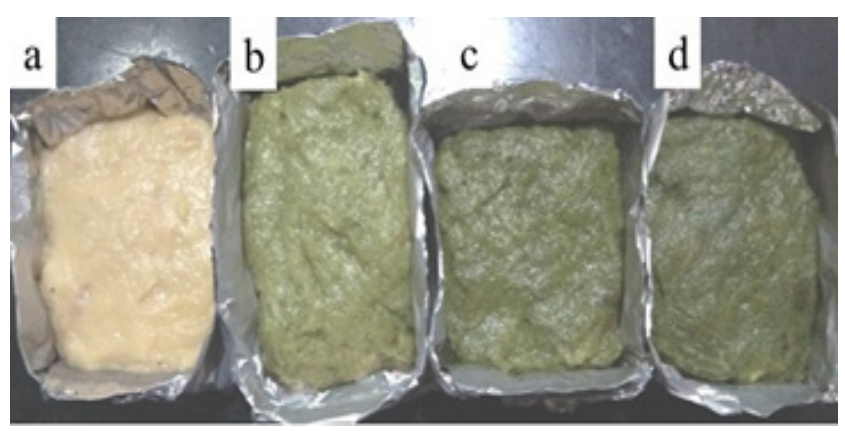

Gambar 1. Nugget ayam dengan fortifikasi tepung daun kelor (a) $0.0 \%$; (b) $0.5 \%$; (c) $1.0 \%$; (d) $1.5 \%$ setelah proses pengukusan

Penelitian lain yang relevan melaporkan bahwa penambahan daun Moringa oleifera dalam pembuatan mie basah, menurunkan nilai organoleptik yang meliputi rasa, warna, tekstur dan aroma (Zakaria et al. 2016). Demikian juga penelitian tentang pembuatan cookies dengan penambahan daun Moringa oleifera (Dewi 2016).

\section{Percobaan Nugget Daging Itik}

\section{Kandungan nutrisi nugget itik}

Kandungan nutrisi terhadap nugget itik yang difortifikasi dengan tepung daun kelor seperti terlihat pada Tabel 4. Digambarkan bahwa kandungan protein kasar semakin meningkat, sedangkan lemak kasar dan kolesterol nugget semakin menurun, seiring meningkatnya persentase penambahan TDK. Hal ini menunjukkan bahwa penambahan TDK dapat meningkatkan nilai nutrisi nugget terutama protein kasarnya meskipun tidak berbeda nyata $(\mathrm{P}>0.05)$.

Kandungan protein pangan yang dikonsumsi, akan menjadi pertimbangan utama dalam menunjang kesehatan, terutama bagi balita. Tabel 4 menggambarkan pengaruh penambahan TDK dalam pembuatan nugget berhasil meningkatkan kandungan Protein Kasar nugget. Semakin tinggi persentase penambahan TDK semakin meningkat juga kandungan Protein Kasar nugget, meskipun tidak berbeda nyata. Hal ini disebabkan daun Moringa oleifera telah dilaporkan banyak penelitian, mengandung protein dan asam amino yang tinggi hingga 30.3\% dengan 19
Tabel 4. Kandungan nutrisi nugget itik dengan penambahan tepung daun kelor (TDK)

\begin{tabular}{cccc}
\hline $\begin{array}{c}\text { TDK } \\
(\%)\end{array}$ & $\begin{array}{c}\text { Lemak Kasar } \\
(\%)\end{array}$ & $\begin{array}{c}\text { Kolesterol } \\
(\mathrm{mg} / 100 \mathrm{~g})\end{array}$ & $\begin{array}{c}\text { Protein Kasar } \\
(\%)\end{array}$ \\
\hline 0 & $3.81 \pm 0.57 \mathrm{a}$ & $55.3 \pm 2.26 \mathrm{a}$ & $14.26 \pm 1.13$ \\
0.5 & $2.73 \pm 0.40 \mathrm{~b}$ & $45.4 \pm 1.59 \mathrm{~b}$ & $14.41 \pm 0.80$ \\
1 & $1.91 \pm 0.54 \mathrm{c}$ & $39.7 \pm 2.17 \mathrm{c}$ & $14.57 \pm 1.09$ \\
1.5 & $1.48 \pm 0.27 \mathrm{~d}$ & $31.2 \pm 1.07 \mathrm{~d}$ & $14.62 \pm 0.54$ \\
\hline
\end{tabular}

Rataan pada kolom yang sama dengan superscript yang berbeda menunjukkan berbeda nyata $(\mathrm{P}<0.05)$

kandungan asam-asam amino (Moyo et al. 2011). Peneliti lain melaporkan bahwa kandungan protein daun Moringa oleifera cukup tinggi sebesar 29.6\% (Suhaemi et al. 2018). Kandungan protein kasar nugget itik juga lebih tinggi dibanding nugget ayam (Tabel 2). Sesuai penelitian Elmoursi et al. (2012), bahwa daging itik mengandung kalori yang rendah dan protein yang lebih tinggi dibanding daging ayam.

Tabel 4 juga menggambarkan bahwa kandungan lemak dan kolesterol nugget itik lebih rendah dibanding dengan nugget ayam (Tabel 2). Hasil ini didukung oleh penelitian yang melaporkan bahwa kandungan lemak daging itik, lebih rendah dibandingkan dengan daging ayam (Adzitey et al. 2012).

Hasil ANOVA menunjukkan bahwa dosis penggunaan TDK menghasilkan perbedaan pengaruh yang sangat nyata terhadap kandungan lemak kasar dan total kolesterol nugget ayam $(\mathrm{P}<0.01)$. Berdasarkan uji berjarak berganda duncan juga didapatkan perbedaan yang sangat nyata $(\mathrm{P}<0.01)$ terhadap kandungan lemak kasar dan kolesterol nugget setiap penambahan dosis TDK dari $0.0 \%$ sampai $1.5 \%$. Daun Moringa oleifera mengandung zat bioaktif yang tinggi termasuk di dalamnya saponin yang dapat menurunkan kandungan total kolesterol produk pangan (Vázquez-León et al. 2017).

\section{Nilai organoleptik nugget itik}

Selain kandungan nutrisi, tidak kalah penting yang menjadi pertimbangan masyarakat adalah tingkat kesukaan terhadap suatu pangan. Hasil uji organoleptik yang meliputi rasa, tekstur dan warna dari nugget itik, dengan persentase penambahan TDK yang berbeda dapat dilihat pada Tabel 5 . Hasil tersebut menggambarkan bahwa nilai rasa, tekstur dan warna nugget ayam (Tabel 3) lebih tinggi disbanding nugget itik. Rataan skala penilaian terhadap rasa nugget itik berada

Tabel 5. Skala uji organoleptik nugget itik dengan penambahan tepung daun kelor (TDK)

\begin{tabular}{cccc}
\hline TDK $(\%)$ & Rasa & Tekstur & Warna \\
\hline 0 & $3.82 \pm 0.60 \mathrm{a}$ & $2.87 \pm 0.52 \mathrm{a}$ & $4.14 \pm 0.60 \mathrm{a}$ \\
0.5 & $4.06 \pm 0.59 \mathrm{~b}$ & $3.67 \pm 0.60 \mathrm{~b}$ & $3.84 \pm 0.59 \mathrm{~b}$ \\
1 & $3.74 \pm 0.59 \mathrm{~b}$ & $3.42 \pm 0.54 \mathrm{c}$ & $3.61 \pm 0.53 \mathrm{c}$ \\
1.5 & $3.70 \pm 0.46 \mathrm{c}$ & $3.04 \pm 0.35 \mathrm{~d}$ & $3.02 \pm 0.46 \mathrm{~d}$ \\
\hline
\end{tabular}

Rataan pada kolom yang sama dengan superscript yang berbeda menunjukkan berbeda nyata $(\mathrm{P}<0.05)$ 
pada skala 3.70 sampai 3.82, lebih rendah dibanding nugget ayam yang mendapat nilai antara skala 4.20 hingga 4.82 .

Hasil analisis ANOVA menunjukkan rasa, tekstur dan warna nugget sangat nyata menurunkan sejalan dengan peningkatan penambahan TDK $(\mathrm{P}<0.01)$. Berdasarkan Tabel 5, nilai rasa nugget itik masih termasuk mendekati kategori suka, sedangkan untuk nugget ayam seluruh perlakuan penambahan TDK berada pada skala antara suka hingga sangat suka. Semakin tinggi prosentase penambahan TDK, mengakibatkan menurunnya nilai skala rasa nugget.

Tekstur nugget itik tanpa penambahan TDK $(0.0 \%)$ menghasilkan skala terendah (2.87), dan meningkat dengan penambahan $0.5 \%$ TDK, kemudian turun kembali pada penambahan 1.05 dan $1.5 \%$. Hal ini menunjukkan bahwa penambahan TDK membantu menurunkan kepadatan nugget yang dihasilkan, namun penambahan $1.0 \%$ atau lebih justru menghasilkan skala tekstur yang menurun, tetapi masih dalam kategori disukai.

Penambahan TDK untuk keempat perlakuan, memberikan penurunan semua nilai organoleptik yang diukur, terutama untuk nilai warna, namun nilai rasa tidak memberikan penurunan yang besar meskipun hasil ANOVA dan uji lanjut semuanya menunjukkan hasil yang berbeda nyata.

Pengaruh penambahan TDK dalam olahan nugget, sangat mempengaruhi warna yang dihasilkan seperti terlihat pada Gambar 2. Warna nugget yang telah dilapisi tepung roti dan digoreng juga terlihat sangat berubah, seperti terlihat pada Gambar 3. Meskipun demikian, rataan skala yang diberikan panelis masih berada di atas 3 atau masih dapat diterima.

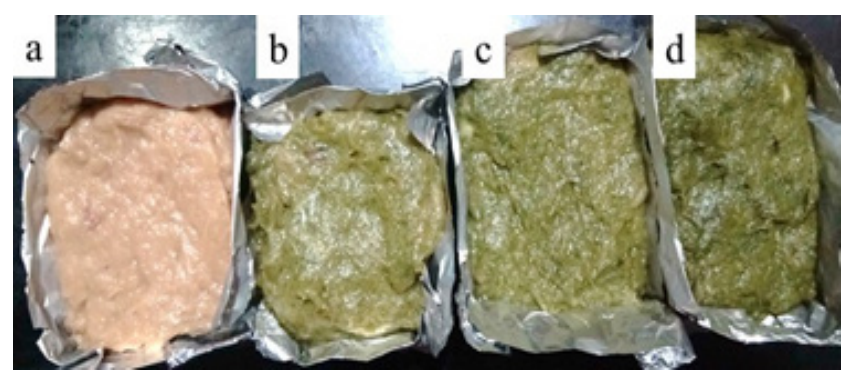

Gambar 2. Nugget itik dengan fortifikasi tepung daun kelor (a) $0.0 \%$; (b) $0.5 \%$; (c) $1.0 \%$; (d) $1.5 \%$ setelah proses pengukusan
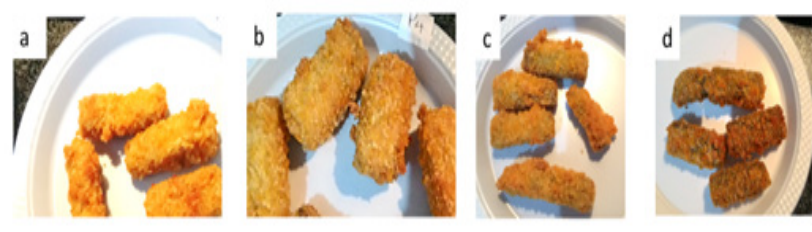

Gambar 3. Hasil nugget itik setelah proses pelapisan dan penggorengan (a) $0.0 \%$; (b) $0.5 \%$; (c) $1.0 \%$; (d) $1.5 \%$.
Berdasarkan nilai organoleptik nugget, sangat relevan dengan penelitian yang melaporkan bahwa, penggunaan daging itik sebagai bahan dasar pembuatan nugget dapat diterima oleh masyarakat akan tetapi belum sepenuhnya mampu mensubtitusi daging ayam, karena berdasarkan rasa nugget dengan bahan dasar daging itik sudah mencapai tingkat disukai oleh panelis (paling rendah pada skala 3.70). Sedangkan nilai warna baru sampai pada kriteria agak disukai karena masih kurang menarik dibandingkan dengan warna nugget ayam (Putri et al. 2019).

\section{KESIMPULAN}

Semakin tinggi dosis penambahan tepung daun kelor (TDK), dapat meningkatkan kandungan protein kasar, serta menurunkan lemak kasar dan kolesterol total hasil nugget. Kandungan nutrisi nugget daging itik lebih baik dibanding nugget ayam, meskipun rasa dan tesktur nugget itik lebih rendah, namun masih masuk kategori baik dengan skala rataan nilai di atas 3 dari maksimal skala 5 yang dinilai panelis.

\section{UCAPAN TERIMAKASIH}

Penelitian terlaksana berkat pendanaan dari Badan Riset Inovasi Nasional (BRIN) Kemenristek Tahun Anggaran 2020. Data yang ditampilkan merupakan bagian dari penelitian Program Insinas Riset Pratama Individu.

\section{DAFTAR PUSTAKA}

Adawiyah, D. R., Tj Muhandri, Subarna, \& Sugiyono. 2019. Pengaruh Fortifikasi Zat Besi Menggunakan FeSulfat, Fe-Fumarat Dan Na Fe EDTA Terhadap Kualitas Sensori Produk-Produk Olahan Tepung Terigu. Jurnal Mutu Pangan: Indonesian Journal of Food Quality. 6(2): 54-62.

Adzitey, Frederick, G. Rusul, \& N. Huda. 2012. Prevalence and Antibiotic Resistance of Salmonella Serovars in Ducks, Duck Rearing and Processing Environments in Penang, Malaysia. Food Research International. 45(2): 947-52.

AOAC. 2005. Official Methods of Analysis. $18^{\text {th }}$ ed. Association of Official Analytical Chemists. Washington, DC.

Aslam, M., F. Anwar, R. Nadeem, U. Rashid, T. G. Kazi, \& M. Nadeem. 2005. Mineral Composition of Moringa oleifera Leaves and Pods from Different Regions of Punjab, Pakistan. Asian Journal of Plant Sciences. 4(4): 417-421.

Citrawidi, T. A., W. Murningsih, \& V. D. Y. B. Ismadi. 2012. Pengaruh Pemeraman Ransum Dengan Sari Daun Pepaya Terhadap Kolesterol Darah dan Lemak Total Ayam Broiler. Animal Agriculture Journal. 1(1): 529-540.

Dewi, F. K. 2016. Pembuatan Cookies Dengan Penambahan Tepung Daun Kelor (Moringa Oleifera) Pada Berbagai Suhu Pemanggangan. Skripsi. Program Studi Teknologi Pangan, Fakultas Teknik Universitas Pasundan. Bandung. 
Dinasih, E., R. Handarini, \& N. Haerina. 2017. Kualitas Sensoris Daging Dari Itik Lokal Jantan (Anas Platyhrinchos) Yang Diberi Larutan Daun Sirih (Pipper Betle Linn) Dalam Pakan Komersil. Jurnal Peternakan Nusantara. 3(1): 1-10.

El-moursi, Abdalla, I. M. Talaat, \& M. A. Bekheta. 2012. Physiological Response of Moringa Oliefera to Stigmasterol and Chelated Zinc. Nusantara Bioscience. 4(3): 118-123.

Gopalakrishnan, L., K. Doriya, \& D. S. Kumar. 2016. Moringa Oleifera: A Review on Nutritive Importance and Its Medicinal Application. Food Science and Human Wellness. 5: 49-56.

Huda, N., O. J. Lin, Y. C. Ping, \& T. Nurkhoeriyati. 2010. Effect Of Chicken And Duck Meat Ratio On The Properties Of Sausage. Int. J. Poult. Sci. 9(6): 550-555.

Huda, N., A. A. Putra, \& R. Ahmad. 2011. Potential Application Of Duck Meat For Development Of Processed Meat Products. Poult. Sci. 1(1): 1-11.

Immy, S. R., E. Aryanti, \& Suripto. 2015. Phytochemical Content of Some of Local Plant Species Frequently Used as Raw Materials for Traditional Medicin. Proseding Seminar Nasional Masyarakat Biodiversity Indonesia. 1(2):388-391.

Lestari, D., Rukmiasih, T. Suryati, P. S. Hardjosworo, \& J. A. Lase. 2020. Komposisi Asam Lemak dan Kadar Malondialdehida Daging Itik Lokal yang Diberi Antioksidan Alami. Jurnal Ilmu Produksi dan Teknologi Hasil Peternakan. 8(3): 117-123.

Lestari, F. E. P., Jakaria, \& Rukmiasih. 2015. Sensori dan Karakteristik Asam Lemak Daging Itik Cihateup, Alabio dan Silangannya. Jurnal Sains Terapan. 5(1): $17-25$.

Moyo, B. P., J. Masika, A. Hugo, \& V. Muchenje. 2011. Nutritional Characterization of Moringa (Moringa oleifera Lam.) Leaves. African Journal of Biotechnology. 10(60): 12925-12933.

Olmedilla-A, Begoña, F J-Colmenero, \& F. J. SánchezMuniz. 2013. Development and Assessment of Healthy Properties of Meat and Meat Products Designed as Functional Foods. Meat Science. 95(4): 919-930.
Oyeyinka, A. T., \& S. A. Oyeyinka. 2016. Moringa oleifera as a Food Fortificant: Recent Trends and Prospects. Journal of the Saudi Society of Agricultural Sciences Open acces (March).

Putri, W. A., S. Wibowo, \& L. Silitonga. 2019. Kualitas Kimia dan Nilai Organoleptik Nugget Daging Itik Dengan Menggunakan Bahan Pengisi yang Berbeda. Jurnal Ilmu Hewani Tropika. 8 (1): 36-41.

Rahmawati, P. S., \& A. C. Adi. 2017. Daya Terima dan Zat Gizi Permen Jeli dengan Penambahan Bubuk Daun Kelor (Moringa Oleifera). Media Gizi Indonesia. 11(1): 86.

Saini, R. K., I. Sivanesan, \& Y. S. Keum. 2016. Phytochemicals of Moringa Oleifera: A Review of Their Nutritional, Therapeutic and Industrial Significance. 3 Biotech. 6(2): 23.

Suhaemi, Z. 2011. Diktat Metode Penelitian dan Rancangan Percobaan. Fakultas Pertanian Universitas Tamansiswa. Padang.

Suhaemi, Z, W. Anwar, T. Sumarni, M. Irgantoro, \& Yusniati. 2018. Introduksi Teknologi Pengolahan Daun Kelor Yang Mendukung Ekonomi Masyarakat Di Posdaya Beringin Sakti. Jurnal Hilirisasi IPTEKS. 14): 204-213.

Thomas, R. H., M. A. Bernards, E. E. Drake, \& C. G. Guglielmo. 2010. Changes in the Antioxidant Activities of Seven Herb and Spice Based Marinating Sauces after Cooking. Journal of Food Composition and Analysis. 23(3): 244-252.

Vázquez-León, L. A., D. E. Páramo-Calderón, V. J. Robles-Olvera, O. A. Valdés-Rodríguez, A. Pérez-Vázquez, M. A. García-Alvarado, \& G. C. Rodríguez-Jimenes. 2017. Variation in Bioactive Compounds and Antiradical Activity of Moringa oleifera Leaves: Influence of Climatic Factors, Tree Age, and Soil Parameters. European Food Research and Technology. 243(9): 1593-1608.

Zakaria, Nursalim, \& A. Tamrin. 2016. Pengaruh Penambahan Tepung Daun Kelor Terhadap Daya Terima Dan Kadar Protein Mie Basah. Media Gizi Pangan. 21(1): 73-78. 